\title{
CANADIAN COUNCIL OF PROFESSIONAL ENGINEERS AND SCIENTISTS
}

Minutes of the Twentieth Meeting of the

Canadian Council of Professional Engineers $\&$ Scientists held in Ottawa, Cnt., on March 8, 1948.

(505) The meeting was held in Salon " $A$ " of the Chateau Laurier, Ottawa on Monday, March 8th and was called to order at $10 \mathrm{a} . \mathrm{m}$. by the Chairman, Mr. W. J. Gibson.

Those in attendance were: The Chairman, Mr. W. J. Gilson and Mr. D. G. Geiger, American Institute of Electrical Engineers, Canadian District; the Vice-Chairman, Dr. J. F. Booth and Dr. C. K. Johns, Agricultural Institute of Canada; Dr. F. S. Howes and Mr. F. R Park, Institute of Radio Engineers, Canadian Council; Mr. J. R. Kirkconnel, Canadian Institute of Mining and Metallurgy; Mr. W. P. Dobson, Canadian Association of Physicists; Mr. T. W. Smith and Mr. G. T. Page, The Chemical Institute of Canada; Mr. M. J. Aykroyd, Associations of Professional Engineers of Ontario, Manitoba, Saskatchewan, Alberta and British Columbia; Mr. G. Tuns, tell, Canadian Society of Forest Engineers; Mr. H. J. Chambers, Dominion Council of Federated Professional Employees; $M r$. W. Balharrie, Royal Architectural Institute of Canada; Miss M. St. C. Clark, Canadian Dietetic Association; Mr. H. W. Lea; Mr. L. L. Bolton, Liaison Officer and Miss H. K. Gray.

Mr. F. L. Lawton, American Institute of Electrical Engineers, Canadian District and Colonel J. H. Jenkins, Canadian Society of Forest Engineers advised of their inability to attend; advice was also received from the Canadian Institute of Mining and Metallurgy designating Mr. L. L. Bolton as proxy for Dr. A. E. Cameron.

(506) Mr. Bolton pointed out some errors in the minutes of the previous meeting. In Minute 490, Page 3, Line 3, after the second word, the words "uniformly high" should be inserted. In minute 498, Page 5, regarding the auditors, the name "F. MacLeod" should read, "H. McLeod".

It was moved by $\mathrm{Dr}$. Howes, seconded by $\mathrm{Mr}$. Geiger and carried un animously that the Minutes of the previous meeting be adopted, as amended.

(507) Secretary's Progress Report.

In the absence of the Secretary due to illness, Mr. Bolton read the report as follows:

Minute 486-Registration of Professional Engineers and Scientists

Co-operating bodies were furnished with copies of this minute. Minute 487-Parliamentary and Scientific Committee

This minute was quoted to Mr. A. E. MacRae, the Council's representative on the Interim Committee.

Minute 488-Re Function of E. and P. Division of National Employment Service.

Reminders of the desire of Council to receive data of interest were distributed to the members and alternates, and to secretaries of co-operative organizations. 
Minute 489-Labour Legislation, Bill 338 of 1947.

This minute was quoted to Mr. A. E. MacRae, Chairman of the Committee on Collective Bargaining.

Minute 492-Student Guidance Booklet

Advice was sent to Colonel J. H. Jenkins of his appointment as representative of Council on the Canadian Committee for Student Guidance in Science and Engineering.

Minute 493-Responsibility Pay for Officers in the Services

The completion of the document to be circulated has been delayed owing to the illness of the Secretary. This should go out within the next three or four weeks. Minute 501-Tariff on Engineering Plans.

An endorsement of Dr. G. B. Langford's presentation of the Council's views was sent to Mr. K. W. Taylor, Assistant Deputy Minister of Finance, Ottawa.

(508) Parliamentary and Scientific Committee-Ref. Minute 487.

The Chairman reported that a letter had been written to The Right Honourable C. D. Howe concerning the establishment of a Parliamentary and Scientific Committee and that a reply had been received.

Mr. Bolton reported that the Committee of Three (Draft Constitution Sub-Committee of the Interim Committee of Ten) had drafted a Constitution for the Parliamentary and Scientific Committee and that this draft had been submitted to the Committee of Ten.

After considerable discussion the Council reaffirmed its support of the desirability of establishing a Parliamentary and Scientific Committee provided it is truly representative of Parliament and of national engineering. and science groups.

It was further agreed to encourage the calling of a meeting of the Committee of Ten at an early date and to review the situation at the next meeting of Council.

(509) Labour Legislation-Bill 338. Ref. Minute 489.

The Chairman reviewed briefly the history of the development of Dominion Government legislation on collective bargaining for professional engineers and scientists with the Order-in-Council P.C. 1003 and leading up to the brief of February 13th, 1947, presented by Council on the draft Labour Bill later presented to Parliament as Bill 338. There was a great deal of discussion concerning Council's past and possible future action in connection with this issue.

The Chairman and Mr. Smith both referred to some development of opinion with reference to the possibility of exclusion of professional engineers and scientists from the collective bargaining procedures set out in the proposed Bill. Mr. Chambers pointed out that exclusion of professional engineers and scientists from the terms of the Bill would probably nat give them much protection due to the manner in which Labour Boards classify workers according to function. Dr. Howes reminded the Council that the rank-and-file members of the co-operating groups had voted overwhelmingly for collective bargaining in groups of their own choice. The request that 
professional engineers and scientists be excluded from the provisions of the Bill, while apparently a move to protect the professional workers from the Labour Unions would, if granted, also deprive them of their right to bargain. collectively should they so desire. Inclusion of professionals under the provisions of the Bill not only preserves their right to bargain collectively but also provides the means of protecting them from the Unions if they organize and, as a group, seek such exclusion in specific cases.

Mr. Chambers indicated that if faced with the alternatives of accepting membership in technical groups which were free to bargain or of rejecting such members as detrimental to their professional status, a great many professional engineers and scientists would accept the first alternative simply because of the increased remuneration which they could expect through collective bargaining procedures.

The Chairman read a copy of the brief which had been submitted to the Minister of Labour on February 13th, 1947, wherein it had requested exclusion of professional persons from bargaining except through units of their own selection.

Comment was made that no formal submission of Council's attitude had been made to Parliament or to any member of the Government subsequent to the introduction of Bill 338 in the House of Commons on June 17 th, 1947.

After further discussion, it was moved by Mr. Aykroyd, seconded by $\mathrm{Mr}$. Smith and carried unaninnously that the present Standing Committee on Collective Bargaining be increased by the addition of two members, Mr. D. G. Geiger of the AIEE and a representative selected by The Chemical Institute of Canada and that this enlarged committee be convened in Toronto within the next ten days with $\mathrm{Mr}$. Chambers as convenor; that the Committee prepare a plan of action for the Chairman of the Standing Committee, Mr. MacRae, such plan to be based on instructions provided by the Council.

It was moved by Mr. Geiger, seconded by Dr. Howes and carried unanimously, that the Council, having received no indication in writing that any constituent body is at variance with the course of action outlined in the Secretary's memorandum of November 25th, 1947, the Standing Committee on Collective Bargaining is instructed to proceed accordingly.

(510) Advertisements of the Civil Service Commission. Ref. Minute 490.

It was reported that Mr. Goudge's report had just been received and that it would be reproduced and circulated to co-operating bodies.

Mr. Aykroyd reported that the question of securing greater uniformity in the Provincial Engineers Acts would be raised at the next meeting of the Dominion Council of Professional Engineers.

(511) Use of Words "Engineer" and "Engineering". Minute 491.

$\mathrm{Mr}$. Bolton reported that word had been received from two more prov. inces, Quebec and Manitoba, regarding the prohibition of the use of the words "engineer" and "engineering" in the proposed names of companies seeking provincial incorporation. It was also reported that the Department of the Secretary of State will place this item on the agenda of the next Dominion-Provincial Conference on Uniform Legislation. 
Mr. Aykroyd intimated that a progress report on this matter would be of value to him.

(512) Student Guidance Booklet-Ref. Minute 492.

Colonel Jenkins, Council representative on the Committee for Student Guidance, had submitted a report of a meeting of that Committee which was read by Mr. Tunstell. Mr. Bolton reported that the information requested by Colonel Jenkins had been supplied.

It was moved by Mr. Geiger, seconded by Mr. Dobson and carried unani. mously that Colonel Jenkins' report be accepted and that he be thanked for his services to the Council.

(513) U.N.E.S.C.O.-Ref. Minute 494.

At the last meeting of Council, it had been proposed by Mr. Carlyle of the Canadian Institute of Mining and Metallurgy that Dr. F. H. Sexton be asked to represent the Council on the Committee for Reconstruction through UNESCO. The Chairman reported he had written to Dr. Sexton and had received a reply from him which implied that he would be willing to represent the Council on that Committee but had not explicitly said no. It was agreed that the Chairman should continue his correspondence with Dr. Sexton and if the latter is willing to act this information will be passed on to $\mathrm{Mr}$. Fraser of the Reconstruction Committee.

(514) American Society of Mechanical Engineers-Ontario Section. Ref. Min. 496.

Mr. Dobson reported that further talks had been held and that he would report again at the next meeting.

(515) Restoration of Duty on Engineers Plans-Ref. Minute 501.

It was reported by the Chairman that a letter had been written to the Dept. of Finance regarding this matter and that a reply had been received. After some discussion which revealed both the importance of this problem and the lively interest being taken in it, it was agreed that this item should appear on the agenda of the next meeting.

(516) Name of the Council-Ref. Minute 503.

Mr. Dobson suggested that the name of the Council might be changed to "Canadian Science Council" as one which would be somewhat handier than the present one. Discussion indicated that the majority of those present were in favour of retaining the present name of the Council, at least for the time being.

(517) National Development Committee-Ref. Minute 470.

The Chairman read a letter sent by Dr. Bates, Chairman of the Standing Committee on National Development to members of his Committee. After some discussion regarding the relation of the work which Dr. Bates proposes and that coming within the terms of reference of some Government Committee as, for example, The Dominion Coal Board, it was agreed to let the matter stand over for discussion at the next meeting.

(518) Finanaces.

Due to illness of the Secretary, the trial balance for this meeting was not available. 
It was reported that the credit balance of the Council a few days before the meeting was approximately $\$ 1,000$.

Messrs. Losee and McLeod had been approached with a view to acting as auditors for 1947 and had expressed their willingness to do so.

(519) Annual Report.-Ref. Minute 499.

The meeting was advised that the Annual Report had been prepared and copies sent to the Chairman and to Dr. Howes. Dr. Howes had made minor changes in the Report and it was agreed that it should be circulated to all co-operating bodies as soon as possible.

New BuSINEsS

(520) Mimeographing Machine.

The Chairman reported that the Secretary had been offered a Gestetner Mimeographing machine which the Agricultural Institute was turning in at the "turn-in" price of $\$ 77.50$. Since the need for such a machine had been previously discussed he had authorized the Secretary to purchase the machine. Council agreed that this had been a good move.

(521) Meeting of the UNESCO Scientific Abstracting Committee in Paris.

Mr. Bolton reported that a communication had been received from the Department of External Affairs regarding a meeting of UNESCO to be held in Paris in April. This meeting would have to do with the abstracting of scientific articles and papers and the circulation of same. Mr. Lea sug. gested that a copy of this communication be circulated to co-operating groups. (522) Cost of American Scientific Books in Canada.

The Chairman read a letter from a publishing company concerning the price of American Institute had had an arrangement with American scientific publishing companies for many years whereby the Institute buys books from them and obtains a special discount for its members. It was suggested that Dr. Booth prepare a memorandum on this matter for the Council, and he agreed to do so.

(523) Income Tax on Annual Dues for Professional Association Memberships.

It was recalled that a case of deduction of lawyers professional society due from Income Tax returns had been upheld by a Manitoba Court and although the Department of Finance could take action to have this judgment set aside, this had not been done so far as was known. Because of its bearing on the situation of professional engineers and scientists, it was agreed that Mr. Bolton should check up on the present legal status of this matter. (524) Model Act for Scientists.

Mr. Dobson reminded the Council that the physicists had raised the question concerning the possibility of the broadening of the Engineer's Acts to include scientists. After some study, it had been agreed that this may be a very difficult thing to accomplish. However, since almost none of the groups of scientists had so far obtained legislation to set up registering bodies for themselves, it was conceivable that a model act might be prepared which would take care of most of the non-engineering groups of professional scientists.

It was moved by $\mathrm{Mr}$. Dobson, seconded by $\mathrm{Mr}$. Howes and carried unanimously that the Chairman set up a Committee to study this matter and re- 
port back to Council.

(525) Stationary Engineers.

Mr. Aykroyd raised the question as to whether the Civil Service Commission proposed to discontinue the use of the term "Stationary Engineers" in their classifications. Mr. Bolton reported that the Civil Service Commission had dropped the class title "Stationary Engineman" and had substituted for it "Stationary Engineer (Heat or Power)".

(526) Salaries of Engineering and Science Teachers

Mr. Aykroyd raised the question concerning the possibility of doing something about the salaries paid by Canadian universities to their teachers in engineering and science. He reported that the American Society of Civil Engineers had prepared a report on this matter with recommended salary levels for different academic grades. He felt that Council should obtain a copy of this report and see what might be done to make it applicable to our Canadian situation. The Chairman suggested that the Report be obtained and studied by Dr. Howes who could report back to Council at the next meeting, and he agreed to do so.

(527) Membership Lists

It was reported that Dr. Howes had undertaken to make a study of the membership lists of the co-operating bodies with a view to determining what degree of overlapping in membership exists. It was agreed that the cooperating bodies should be asked to give all possible support to this study.

(528) Time of Meeting

Mr. Smith raised the question as to whether it would be possible to advance the normal hour of convening each meeting from 10 a.m. to 9.30 a.m. in order that a correspondingly earlier adjournment would follow. It was agreed that this procedure would be tried at the next meeting.

(529) Illness of the Secretary

The Chairman expressed the wish for the speedy recovery of Mrs. White and this was heartily concurred in by all present.

(530) Next Meeting

It was agreed that the next meeting should be held in Ottawa at 9.50 a.m. on May 10th, 1948.

The meeting adjourned at 4.35 p.m.

\section{CANADIAN PULP AND PAPER ASSOCIATION_SUMMER MEETING-WOODLANDS SECTION}

The summer meeting of the Woodlands Section, CPPA, will be held August 18th to 20th (Wednesday to Friday) at Dawson College, St. Johns, P.Q., about 30 miles southeast of Montreal.

The meeting will be devoted almost entirely to display and demonstration of logging equipment and products of interest to woods operators, for which purpose the College facilities are particularly well adapted.

There will be ample opportunity for discussion, and the showing of moving pictures in the theatre.

Accommodation for the delegates will be in buildings similar to those used at the 1947 summer meeting at Petawawa. 